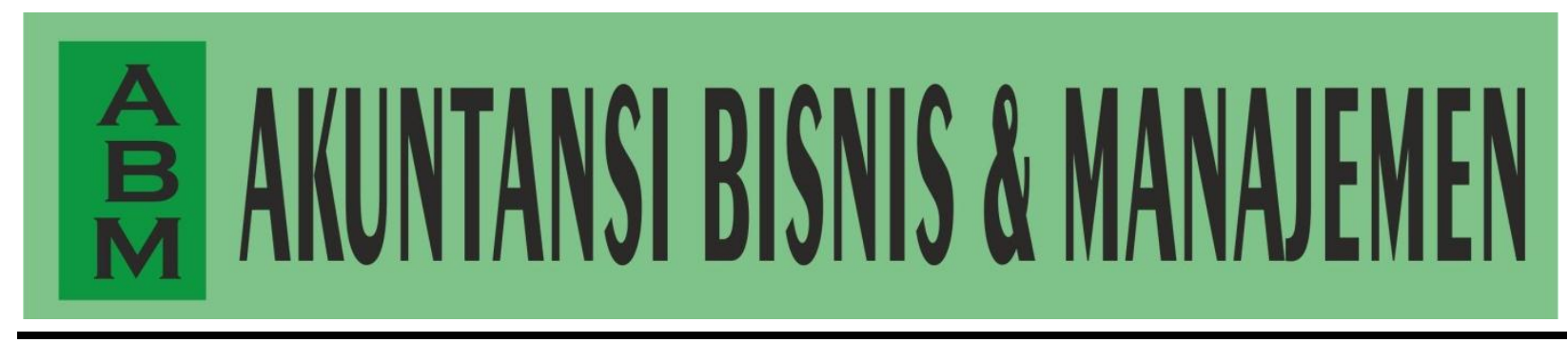

\title{
DAMPAK MEDIASI DARI LEVERAGE TERHADAP HUBUNGAN CURRENT RATIO DAN RETURN ON ASSETS
}

\author{
Santoso F. Lubis ${ }^{1)}$ dan Francis Hutabarat ${ }^{2)}$ \\ Fakultas Ekonomi Universitas Advent Indonesia \\ Jl Kolonel Masturi No. 288, Parongpong, Bandung Barat 40559 - Jawa Barat \\ E-Mail: santosolubis314@gmail.com
}

DOI: https://doi.org/10.35606/jabm.v27i2.658

\author{
Akuntansi Bisnis dan \\ Manajemen (ABM), \\ Vol. 27 \\ No. 02 \\ Halaman 1 - 11 \\ Bulan Oktober, Tahun 2020
}

ISSN 0854-4190

E-ISSN 2685-3965

\section{Informasi Artikel}

Tanggal Masuk:

3 Juli 2020

Tanggal Revisi:

28 September 2020

Tanggal Diterima:

15 Otober 2020
Abstract

The research objective is to examine the effect of Current Ratio on Return On Assets with Leverage mediation in transportation sector companies listed on the Indonesia Stock Exchange. In this study, the data used are the financial statements of 10 transportation companies for the period 2015-2018. Analysis using multiple linear regression. The results of this study indicate that the Current Ratio does not significantly affect ROA. Current Ratio does not significantly affect Leverage. Leverage variable does not have a significant effect on ROA.

Keywords: Leverage; Current Ratio; Return on Asset

\begin{abstract}
Abstrak
Penelitian ini bertujuan untuk menguji pengaruh Current Ratio terhadap Return On Asset dengan mediasi Leverage pada perusahaan sektor transportasi yang tercatat pada BEI. Pada penelitian ini data yang dipakai adalah laporan keuangan 10 perusahaan transportasi yang terdaftar di BEI (IDX) dengan periode 4 tahun dari 2015-2018. Pengolahan data menggunakan regresi linear berganda. Hasil penelitian ini menunjukkan Current Ratio tidak secara signifikan mempengaruhi ROA. Current Ratio tidak secara signifikan mempengaruhi variabel mediasi Leverage. Variabel Leverage tidak berpengaruh signifikan terhadap ROA.
\end{abstract}

Kata Kunci: Leverage; Current Ratio; Return on Asset. 


\section{PENDAHULUAN}

Laporan keuangan merupakan hal penting yang harus dilakukan oleh perusahaan, karena dibutuhkan oleh banyak pihak untuk berbagai kepentingan. Laporan keuangan disusun dengan tujuan untuk menyediakan informasi keuangan yang berguna untuk investor, pemberi pinjaman, dan kreditor lainnya dalam pembuatan keputusan (IAI, 2016). Dengan adanya laporan keuangan ini, maka pemilik sebuah perusahaan dan para investor tentu dapat mengetahui bagaimana keadaan keuangan dan kinerja perusahaannya. Investor membutuhkan laporan keuangan dalam hal pengambilan keputusan investasi, sedangkan di pihak perusahaan membutuhkan untuk pengambilan keputusan baik jangka pendek maupun panjang.

Berdasarkan laporan keuangan akan dapat dinilai kekayaan sebuah perusahaan dengan membuat analisis rasio profitabilitas yang tampak pada Return on Assets (ROA). Rasio ini menunjukkan kemampuan perusahaan untuk mendapatkan memperoleh laba dengan memaksimalkan seluruh aset yang ada. Perusahaan juga perlu menjaga likuiditas yang tampak dari Current Ratio agar dapat melakukan analisis dan menginterpretasikan posisi kewajiban jangka pendek. Selain itu hal tersebut dapat membantu manajemen dalam memeriksa efisiensi modal kerja. Perusahaan dengan tingkat likuiditas yang tinggi biasanya memiliki kesempatan lebih baik untuk mendapatkan berbagai dukungan dari lembaga keuangan, kreditur, maupun pemasok, sama halnya dengan rasio Leverage yang dicerminkan dari DER. Tujuan utama daripada Leverage adalah untuk memudahkan perusahaan dalam menentukan dan menilai tingkat pengaruh dari utang terhadap pengelolaan aktiva, karena Leverage menunjukkan ukuran bagaimana perusahaan dibiayai oleh hutang.

Tujuan dan fungsi rasio ini saling bersinggungan antar variabel. sebagaimana penelitian yang dilakukan oleh Finky, Wijaya, and Ernawati (2013). Mereka menunjukkan adanya hubungan negatif antara variabel likuiditas yang diproksikan sebagai Current Ratio dan struktur modal yang diproksikan sebagai DER. Hal ini menunjukkan bahwa jika likuiditas perusahaan mengalami peningkatan maka struktur modal perusahaan akan mengalami penurunan. Begitu juga yang dilakukan oleh (Y. Y. D. Putra \& Wiagustini, 2013) yang menyatakan semakin tinggi likuiditas perusahaan semakin tidak mampu secara nyata meningkatkan profitabilitasnya. Sebaliknya semakin tinggi Leverage sebuah perusahaan semakin mampu secara nyata meningkatkan profitabilitasnya.

Sejalan dengan uraian sebelumnya, Tjandra (2015) mengungkapkan bahwa "GCG berpengaruh negatif dan signifikan terhadap profitabilitas, dan GCG melalui leverage memiliki pengaruh positif namun tidak signifikan terhadap profitabilitas. Selain itu leverage berpengaruh positif dan sangat signifikan terhadap profitabilitas". Hasil ini menunjukkan bahwa jika perbandingan keberadaan Leverage tidak dikontrol oleh perusahaan, maka akan menyebabkan penurunan profitabilitasnya, karena pemanfaatan hutang menyebabkan beban bunga yang menetap. Proporsi Leverage yang diproksikan sebagai Debt Equity Ratio (DER) menunjukkan perbandingan 
penggunaan hutang untuk menanggung investasi pada kepemilikan modal.

Selain leverage yang digunakan perusahaan untuk melakukan penilaian, current rasio juga dibutuhkan untuk untuk menunjukkan kemampuan perusahaan dalam memenuhi kewajiban jangka pendeknya. Current Ratio yang rendah dalam sebuah perusahaan biasanya diasumsikan karena disebabkan oleh masalah likuiditas, sebaliknya juga perlu dipertimbangkankan bahwa Currrent Ratio yang terlalu tinggi, belum tentu membuat kondisi perusahaan menjadi lebih bagus ke depannya. Hal ini dikarenakan akan menimbulkan banyaknya dana yang tidak dimanfaatkan, dan pada akhirnya akan mengurangi potensi perusahaan dalam meningkatkan laba. Menurut penelitian yang yang dilakukan Alpi and Gunawan (2018) Current Ratio (CR) mempunyai pengaruh signifikan pada ROA perusahaan. dengan demikian berdasarkan penelitian tersebut dapat diberikan analisa bahwa Current Ratio perusahaan sangat berpengaruh pada peningkatan, ataupun penurunan profitabilitas perusahaan. Current Ratio dan Leverage tentunya diinginkan dapat meningkatkan profitabilitas perusahaan dalam jangka panjang.

Kajian yang dilakukan oleh peneliti saat ini merujuk apa yang diungkap oleh Otoritas Jasa Keuangan (OJK) mencatat " return on asset (RoA) atau rasio profitabilitas multifinance pada Semester I 2019 ada di angka 4,67\%. Angka tersebut naik dari Semester I 2018 yakni sebesar 4,38\%. Saat ROA mengalami kenaikan, di sisi lain penjualan kendaraan menurun. Hal ini sebagaimana data Gabungan Industri Kendaraan Bermotor (Gaikindo) Perdagangan mobil pada Juni 2019 menggapai 59.539 nyaris mengalami penurunan 30\% tepat pada 29,24\% sedangkan pada Mei 2019 telah mencapai target 84.146 unit. akan tetapi dilihat dari tahun sebelumnya omset pada bulan Juni bahkan mengalami kenaikan dikarenakan penghasilan yang diperoleh pada Juni 2018 mobil yang terjual sampai 58.842 unit"(Ghifari, 2019).

Dari kasus ini dapat kita lihat adanya masalah yang pada data rasio profitabilitas yang semakin meningkat, sementara di sisi lain penjualan kendaraan menurun. Dengan melakukan analisis terhadap kasus ini tantangan yang akan dihadapi oleh para industri pembiayaan di semester II yakni, bagaimana cara menjaga kualitas piutang di saat daya beli yang semakin menurun. Dengan demikian berdasarkan uraian sebelumnya peneliti mempunyai motivasi dalam penelitian ini. dengan tujuan bahwa, penelitian ini hendak melihat bagaimana Leverage dapat memediasi pengaruh antara Current Ratio dan Return On Asset dengan analisa yang dilakukan pada perusahaan segmen transportasi yang telah tercatat dalam bursa efek Indonesia.

\section{KAJIAN PUSTAKA DAN HIPOTESIS}

\section{Leverage}

Leverage merupakan sebuah kemampuan perusahaan dalam memanfaatkan penggunaan dana secara efisien yang memiliki biaya tetap dalam upaya memenuhi pencapaian dengan meningkatkan kekayaan. Leverage pada umumnya dipergunakan sebagai cara beberapa perusahaan untuk memaksimalkan modal dengan tujuan memperoleh laba. Dampak positif dari Leverage ini adalah semakin tinggi nilai Leverage 
sebuah perusahaan maka nilai perusahaan juga akan semakin meningkat. Yang dimana telah dibuktikan dengan penelitian terdahulu oleh Suwardika and Mustanda (2017) menyatakan Leverage berpengaruh signifikan dan memiliki arah yang positif terhadap nilai perusahan. Dampak negatif daripada Leverage ini adalah saat Leverage meningkat maka profitabilitas yang diperoleh akan menurun. Dan telah dibuktikan dengan penelitian W. Y. Putra and Badjra (2015) yang menyatakan Leverage berpengaruh negatif dan signifikan terhadap profitabilitas. Rasio hutang yang peneliti gunakan pada karya ilmiah ini diukur menggunakan Debt to Equity Ratio (DER). Debt to Equity Ratio menggambarkan rasio yang dipakai dalam menghitung hutang dengan ekuitas. DER ini memiliki fungsi untuk memberikan perbandingan modal awal yang diperoleh atas hutang. Secara Formulasi Rumus Debt Equity Ratio adalah:

$$
\text { Debt Equity Ratio }=\frac{\text { Total Liabilities }}{\text { Equity }}
$$

Untuk melakukan pengukuran kemampuan perusahaan untuk melunasi kewajiban. contohnya: kredit pinjam tergolong bunga. Untuk mengukur keseimbangan pada nilai aktiva secara khusus aset tetap bersama modal. Melakukan penilaian berapa besarnya aset yang ditanggung oleh hutang. Melakukan penilaian berapa besarnya pengaruh utang perusahaan terhadap aktiva. untuk menunjukkan seberapa besar nilai modal sebagai penjamin kewajiban lancar. Untuk mengetahui total hutang dalam waktu dekat yang akan ditagih.

\section{Current Ratio}

Current Ratio merupakan sebuah rasio yang digunakan untuk mengetahui tingkat kemampuan perusahaan untuk memenuhi hutang dan harta lancarnya. Brigham and Houston (2011) menyatakan Current Ratio menjadikan tolak ukur secara umum yang digunakan untuk memenuhi hutang dalam waktu jangka pendek. Current Ratio, digunakan untuk melakukan pengukuran kinerja sebuah perusahaan untuk melunasi hutang lancar yang diperkirakan dalam waktu dekat akan jatuh tempo (Kasmir, 2016). Dampak positif daripada perubahan besar atau kecilnya Current Ratio sebuah perusahaan adalah, perusahaan yang mampu membayar utang jangka pendeknya yang jatuh tempo, akan memperoleh kepercayaan dari kreditur dan memperlancar pemasokan barang produksi. Pernyataan ini telah dibuktikan dengan penelitian terdahulu oleh Rahayu and Hari (2016) dengan menyatakan bahwa Current Ratio berpengaruh positif signifikan terhadap profitabilitas perusahaan. Dampak negatif daripada besar atau kecilnya Current Ratio perusahaan ialah bahwa meningkatnya nilai Current Ratio perusahaan, pada umumnya akan menyebabkan penurunan pada 
Dividend Payout Ratio. Hal ini telah dibuktikan dari penelitian terdahulu yang dilakukan oleh Yasa and Wirawati (2016). Mereka menyatakan Current Ratio berpengaruh negatif dan signifikan secara statistik terhadap Dividend Payout Ratio.

Secara Formulasi rumus CR adalah

$$
\text { Current Ratio }=\frac{\text { Current Asset }}{\text { Current Liabilities }}
$$

\section{Return On Assets (ROA)}

Profitabilitas merupakan sebuah perusahaan individu maupun organisasi yang memiliki ukuran kemampuan dalam memanifestasikan keuntungan serta mengelola modal untuk dimanfaatkan. Profitabilitas yang lazim dipakai dalam sebuah perusahaan yakni fase pengembalian aset (ROA) serta fase pengembalian utang (ROE)., namun profitabilitas yang didasarkan pada penelitian ini sebagai variabel dependen adalah ROA. ROA merupakan tolak ukur apakah sebuah perusahaan mampu menciptakan penghasilan, terhadap semua aset yang dimiliki oleh perusahaan Syamsudin (2007). Dalam hal untuk meningkatkan ROA sebuah perusahaan dapat dilakukan dengan cara meningkatkan aktiva total dan laba bersih. Maka diperlukan pengelolaan yang efektif dan efisien. Terkait dengan Leverage dalam hal meningkatkan profitabilitas (ROA), dengan peningkatan Leverage yang semakin tinggi, maka akan mampu secara nyata dalam meningkatkan profitabilitas perusahaan. Yang dimana, Leverage menunjukkan jumlah modal yang dibandingkan dengan total aktiva. Secara formulasi rumus ROA adalah:

$$
\text { Return On Asset }=\frac{E A T}{\text { Total Asset }} \times 100 \%
$$

\section{Pengaruh Current Ratio Terhadap ROA}

Sebuah perusahaan yang mempunyai Current Ratio yang besar, tidak akan menjamin hutang perusahaannya akan mampu dibayar. Adanya pengaruh Current Ratio pada ROA telah didasarkan terhadap penelitian terdahulu. Current Ratio memiliki pengaruh positif serta signifikan pada ROA (Saragih, Siahaan, Purba, \& Supitriyani, 2015). Berbeda dengan penelitian sebelumnya Dewi, Cipta, and Kirya (2015) menunjukkan hasil Current Ratio memiliki pengaruh negatif serta signifikan pada ROA, sedangkan penelitian Supardi, Suratno, and Suyanto (2016) menunjukkan hasil Current Ratio berpengaruh positif dan tidak signifikan pada ROA. Kemudian penelitian Enggarwati (2016) menyebutkan Current Ratio berpengaruh positif serta signifikan terhadap profitabilitas, sedangkan penelitian dari Ginting (2018); Octavianty and 
Rachmalia (2013); Saputro and Budhy (2019) membuktikan hasil Current Ratio tidak mempunyai pengaruh signifikan pada ROA.

H1: Current ratio memiliki pengaruh signifikan terhadap ROA.

\section{Pengaruh Current Ratio Terhadap Leverage (DER)}

Semakin tinggi Current Ratio yang dimiliki sebuah perusahaan, maka menunjukkan tentu akan semakin besar aset lancar yang dimiliki perusahaan tersebut, dengan dibandingkan pada kewajiban lancarnya. Sebuah perusahaan dengan tingkat likuiditas yang tinggi, dapat disimpulkan bahwa perusahaan memiliki kelebihan aset lancar yang cukup untuk membiayai operasional perusahaan tanpa melakukan pinjaman.

Hasil penelitia Wulandari (2013) mengungkapkan likuiditas tidak berpengaruh signifikan terhadap Struktur modal yang diproksikan sebagai DER. Hal ini berbeda dengan penelitian yang dilakukan oleh Primantara and Dewi (2016) yang menyatakan likuiditas berpengaruh positif dan signifikan terhadap struktur modal.

H2: Current Ratio memiliki pengaruh signifikan pada Leverage(DER).

\section{Pengaruh Current Ratio dan Leverage (DER) Terhadap Return On Asset(ROA)}

Rasio hutang Leverage yang pertumbuhannya meningkat dalam sebuah perusahaan menunjukkan risiko investasi yang tentu semakin banyak terhadap perusahaan tersebut. Pengaruh antara rasio Leverage terhadap Return On Asset dapat didasarkan pada kesimpulan penelitian terdahulu yang sudah ada. Hasil penelitian yang dilakukan oleh Sunarto and Budi (2009) menemukan bahwa rasio Leverage dengan menggunakan rasio hutang DER mempunyai pengaruh negatif pada ROA perusahaan, kemudian penelitian Ratnasari (2016) mengungkapkan hasil Leverage mempunyai pengaruh signifikan pada ROA. Hal ini berbeda dengan hasil penelitian Wartono (2018) yang mengungkapkan hasil DER berpengaruh akan tetapi tidak signifikan terhadap ROA. Kemudian, ditemukan dengan hasil penelitian yang menunjukkan hasil Leverage berpengaruh signifikan serta negatif terhadap ROA (Fransisca \& Wijaya, 2019; Sari, 2019) menunjukkan hasil Leverage berpengaruh signifikan serta negatif terhadap ROA.

\section{H3: Current Ratio dan Leverage memiliki pengaruh signifikan terhadap ROA.}

Berdasarkan beberapa kesimpulan dari peneliti yang terdahulu, diketahui hasilnya ada yang sama dan ada pula yang berbeda. Walaupun penelitian ini telah memiliki hasil, penelitian yang lebih dalam diperlukan dengan kondisi tempat penelitian yang berbeda. Hal ini sangat penting untuk mengetahui apakah penelitian ini masih 
berkaitan di dalam kondisi perusahaan. 10 perusahaan transportasi yang telah tercatat dalam bursa efek Indonesia pada tahun 2015-2018 merupakan populasi yang digunakan dalam penelitian ini. Sebagai dependen variabel adalah ROA, sedangkan independen variabel adalah Current Ratio, serta sebuah variabel mediasi yaitu Leverage yang didasarkan pada Debt Equity Ratio.

\section{METODE PENELITIAN}

Peneliti melakukan pembatasan terhadap ruang lingkup masalah, yaitu (1) Beberapa perusahaan transportasi yang berturut turut tercantum dalam periode 20152018, dan (2) Dalam penelitian ini hanya 3 variabel yang digunakan dalam memprediksi ROA pada perusahaan di sektor transportasi yang terdapat di Bursa Efek Indonesia.

Variabel tersebut dikategorikan menjadi dua bagian yaitu: dependen $(X)$ dan Independen ( $\mathrm{Y})$. Variabel Dependen yaitu Profitabilitas merupakan variabel yang dipengaruhi $\mathrm{X}$.

$$
\text { Return On Asset (ROA) Return On Asset }=\frac{E A T}{\text { Total Asset }} \times 100 \%
$$

Variabel Independen adalah variabel yang mempengaruhi Y.

Leverage (DER)

$$
\text { Debt Equity Ratio }=\frac{\text { Total Liabilities }}{\text { Equity }}
$$

Current Ratio(CR).

$$
\text { Current Ratio }=\frac{\text { Current Asset }}{\text { Current Liabilities }}
$$

Populasi yang ditentukan pada penelitian ini yakni 10 perusahaan transportasi di BEI pada tahun 2015-2018, sedangkan sampel yang digunakan berjumlah 40. Populasi merupakan keseluruhan bobot baik melalui tolak ukur dan kalkulasi serta bersifat kuantitatif maupun kualitatif atas karakteristik yang berhubungan pada serangkaian objek maupun subjek yang lebih pasti. Sampel merupakan beberapa atas bagian subjek yang terkandung di populasi yang diteliti, yang mampu secara representatif mewakilkan objeknya.

Peneliti menggunakan jenis data sekunder dengan metode kuantitatif yang telah diproses di laporan keuangan perusahaan transportasi dan telah tercatat di bursa efek Indonesia. Model analisis data yang digunakan pada penelitian ini menggunakan analisis regresi linear berganda. Analisis yang terdapat pada penelitian, baik dalam bentuk apapun menggambarkan bagaimana cara berpikir. Pernyataan tersebut 
berhubungan dengan evaluasi sistem pada sebagian untuk memutuskan korelasi tertentu. data yang dibutuhkan pada penelitian ini didukung dengan bantuan komputer software SPSS.

\section{HASIL DAN PEMBAHASAN}

\section{Pengaruh Current Ratio terhadap Debt Equity Ratio}

Tabel 1. Pengaruh Current Ratio Terhadap Debt Equity Ratio

Standardized

\section{Unstandardized Coefficients Coefficients}

\begin{tabular}{|c|c|c|c|c|c|c|}
\hline Model & & B & Std. Error & Beta & $\mathrm{t}$ & Sig. \\
\hline 1 & (Constant) & .686 & .367 & & 1.872 & .069 \\
\hline & CR & .038 & .180 & .035 & .213 & .832 \\
\hline
\end{tabular}

a. Dependent Variable: DER

Dari output tersebut dapat kita ketahui nilai koefisien regresi sebesar 0.038 dan nilai Sig p 0.832> 0.05. Dengan demikian Current Ratio (X) tidak secara signifikan mempengaruhi Debt Equity Ratio

Tabel 2. Pengaruh Current Ratio dan Debt Equity Ratio terhadap Return On Assets

\begin{tabular}{|c|c|c|c|c|c|c|}
\hline \multirow{2}{*}{\multicolumn{2}{|c|}{ Model }} & \multicolumn{2}{|c|}{$\begin{array}{l}\text { Unstandardized } \\
\text { Coefficients }\end{array}$} & \multirow{2}{*}{$\begin{array}{c}\text { Standardized } \\
\text { Coefficients } \\
\text { Beta }\end{array}$} & \multirow[b]{2}{*}{$\mathrm{t}$} & \multirow[b]{2}{*}{ Sig. } \\
\hline & & B & Std. Error & & & \\
\hline \multirow[t]{3}{*}{1} & (Constant) & -.110 & .056 & & -1.950 & .059 \\
\hline & $\begin{array}{l}\text { CURRENT } \\
\text { RATIO }\end{array}$ & .028 & .027 & .163 & 1.051 & .300 \\
\hline & LEVERAGE & .044 & .024 & .287 & 1.851 & .072 \\
\hline
\end{tabular}

a. Dependent Variable: ROA

Berdasarkan Tabel 2 tampak bahwa baik current ratio maupun leverage secara ignifikan tidak mempengaruhi Return On Asset. Variabel Current Ratio tidak berpengaruh signifikan terhadap Return On Asset (Y) perusahaan. ini menunjukkan bahwa seberapa besar pengaruh Current Ratio terhadap Return On Asset perusahaan tidak akan selalu sama pada tiap perusahaan.

Hasil penelitian ini didukung oleh penelitian terdahulu oleh Supardi, Suratno dan Suyanto (2016), Saputro (2019), Octavianty dan Rachmalia (2013), Ginting (2018), yang 
menyatakan tidak berpengaruh signifikan terhadap Return On Asset perusahaan. Berbeda dengan penelitian Dewi, Cipta dan Kirya (2015), Saragih (2015), Enggarwati (2016), Alpi dan Gunawan (2018) yang menyatakan adanya pengaruh yang signifikan terhadap Return On Asset perusahaan. Temuan ini juga berbeda dengan penelitian Dewi, Cipta dan Kirya (2015), Saragih (2015), Enggarwati (2016), Alpi dan Gunawan (2018) dan tidak didukung oleh Supardi, Suratno dan Suyanto (2016), Saputro (2019), Octavianty dan Rachmalia (2013), Ginting (2018).

Variabel Current Ratio $(\mathrm{X})$ tidak berpengaruh signifikan terhadap Leverage (DER). Hal Ini menunjukkan dikarenakan Current Ratio tidak terlalu dipertimbangkan pada penyusunan Leverage perusahaan. besarnya likuiditas suatu perusahaan tidak akan menjamin kuatnya kondisi keuangan perusahaan tersebut. Tergantung seberapa aset yang mampu dikonversikan dalam kas untuk melunasi kewajibannya. Hasil penelitian ini didukung oleh Wulandari (2013) dan tidak didukung oleh Primantara \& Dewi (2016).

\section{KESIMPULAN DAN SARAN}

Peneliti menyimpulkan bahwa Current Ratio tidak secara signifikan mempengaruhi Return on Asset. Current Ratio tidak secara signifikan mempengaruhi Leverage (DER), Leverage tidak terbukti secara signifikan berpengaruh terhadap Return on Asset.

Untuk penyempurnaan model disarankan agar peneliti berikutnya disarankan untuk menggunakan proxy yang berbeda contohnya ROE untuk mengukur profitabilitas, sedangkan variabel anteseden lainnya dapat digunakan earning per share. Implikasi yang dapat diambil adalah pengelolaan perusahaan lebih ditekankan pada efisiensi sumber daya perusahaan agar menghasilkan profitabilitas yang tinggi.

\section{DAFTAR PUSTAKA}

Alpi, M. F., \& Gunawan, A. (2018). Pengaruh Current Ratio Dan Total Assets Turnover Terhadap Return On Assets Pada Perusahaan Plastik Dan Kemasan Aksionam, Vol. 17(No. 2), 1-36.

Brigham, F. E., \& Houston, J. F. (2011). Dasar-Dasar Manajemen Keuangan (T. A. A. Yulianto., Trans. 10 ed.). Jakarta: Salemba Empat.

Dewi, N. K. V. C., Cipta, W., \& Kirya, I. K. (2015). Pengaruh LDR, LAR, DER dan CR Terhadap ROA. e-Journal Bisma Universitas Pendidikan Ganesha, Volume 3, 1-10.

Enggarwati, D. (2016). Pengaruh Leverage dan Likuiditas Terhadap Profitabilitas Pada Perusahaan Otomotif di BEI. Jurnal Ilmu dan Riset Manajemen (JIRM), 5(11), 1-15.

Finky, U. V., Wijaya, L. I., \& Ernawati, E. (2013). Faktor - Faktor Yang Mempengaruhi Struktur Modal Pada Industri Property Dan Real Estate Yang Terdaftar Di Bei 
Periode 2008-2011. Calyptra: Jurnal Ilmiah Mahasiswa Universitas Surabaya, Vol.2(No.2), 1-13.

Fransisca, E., \& Wijaya, I. (2019). Pengaruh Leverage, Likuiditas, Pertumbuhan Penjualan Dan Ukuran Perusahaan Terhadap Profitabilitas Perusahaan Manufaktur. Jurnal Manajerial Dan Kewirausahaan, Vol. 1(No. 12), 199-206.

Ghifari, A. (2019). Rasio profitabilitas multifinance semakin menanjak, ini kata APPI Retrieved 15 Oktober, 2020, from https://keuangan.kontan.co.id/news/rasioprofitabilitas-multifinance-semakin-menanjak-ini-kata-appi

Ginting, W. A. (2018). Analisis Pengaruh Current Ratio, Working Capital Turnover, dan Total Asset Turnover Terhadap Return On Asset. Jurnal Ilmiah Kohesi, 15(2), 163172.

IAI. (2016). Kerangka Dasar SAK Umum Retrieved 21 November, 2020

Kasmir. (2016). Analisis Laporan Keuangan: Raja Grafindo Persada.

Octavianty, E., \& Rachmalia, R. R. A. (2013). Analisis Pengaruh Likuiditas terhadap Profitabilitas pada Perusahaan Dagang yang Terdaftar di BEI (2008-2012). Jurnal Ilmiah Manajemen dan Akuntansi Fakultas Ekonomi (JIMAFE), Volume Semester II

Primantara, A. A. N. A. D. Y., \& Dewi, M. R. (2016). Pengaruh Likuiditas, Profitabilitas, Risiko Bisnis, Ukuran Perusahaan, Dan Pajak Terhadap Struktur Modal. E-Jurnal Manajemen Unud, Vol. 5(No. 52696-2726).

Putra, W. Y., \& Badjra, I. B. (2015). Pengaruh Leverage, Pertumbuhan Penjualan Dan Ukuran Perusahaan Terhadap Profitabilitas. E-Jurnal Manajemen Unud, Vo.4(No.7), 2052-2067.

Putra, Y. Y. D., \& Wiagustini, N. L. P. (2013). Pengaruh Likuiditas Dan Leverage Terhadap Profitabilitas Dan Nilai Perusahaan Pada Perusahaan Perbankan Di Bei. Jurnal Wawasan Manajemen, Vol.1(Nomor 2), 215-231.

Rahayu, A. S., \& Hari, M. (2016). Pengaruh Current Ratio dan Quick Ratio terhadap Kebijakan Dividen Melalui Return On Equity Pada Perusahaan Manufaktur yang Terdaftar di BEI Tahun 2014. Ekonomi Bisnis 21(2), 231-240.

Ratnasari, L. (2016). Pengaruh Leverage, likuiditas, Ukuran Perusahaan terhadap Profitabilitas pada perusahaan otomotif di BEI. Jurnal Ilmu dan Riset Manajemen (JIRM), 5(6), 1-15.

Saputro, \& Budhy, F. (2019). Pengaruh Working Capital, Struktur Modal dan Current Ratio terhadap Profitabilitas. JABE (Journal of Applied Business and Economic), 5(3), 177-191. 
Saragih, M., Siahaan, Y., Purba, R., \& Supitriyani. (2015). Pengaruh Current Ratio Terhadap Return On Asset Pada Perusahaan Sektor Aneka Industri Yang Listing Di Bursa Efek Indonesia. Jurnal FINANCIAL, Volume 1(Nomor 1), 19-24.

Sari, N. I. N. D. Y. Y. (2019). Pengaruh Modal Kerja, Leverage, Likuiditas, dan Firm Size terhadap Profitablilitas Sektor Industri Barang dan Konsumsi. Jurnal Ilmu Manajemen (JIM), Vol.7(No.3).

Sunarto, \& Budi, A. P. (2009). Pengaruh Leverage, Ukuran Dan Pertumbuhan Perusahaan Terhadap Profitabilitas. TEMA Vol. 6(edisi 2), 86-103.

Supardi, H., Suratno, H., \& Suyanto. (2016). Pengaruh Current Ratio, Debt To Asset Ratio, Total Asset Turnover Dan Inflasi Terhadap Return On Asset. JIAFE (Jurnal Ilmiah Akuntansi Fakultas Ekonomi), Volume 2(Nomor 2), 16-27.

Suwardika, I. N. A., \& Mustanda, I. K. (2017). Pengaruh Leverage, Ukuran Perusahaan, Pertumbuhan Perusahaan, Dan Profitabilitas Terhadap Nilai Perusahaan Pada Perusahaan Properti. E-Jurnal Manajemen Unud, Vo.6(No.3), 1248-1277.

Tjandra, E. (2015). Pengaruh Good Corporate Governance Terhadap Leverage Dan Profitabilitas Pada Perusahaan Property Dan Real Estate Di Indonesia. Jurnal GEMA AKTUALITA, Vol. 4 ( No. 2), 74-85.

Wartono, T. (2018). Pengaruh Current Ratio (CR) Dan Debt To Equity Ratio (DER) Terhadap Return On Asse t(ROA) (Studi Pada Pt Astra International, Tbk) J. KREATIF, Vol.6(No. 2), 78-97.

Wulandari, D. R. (2013). Pengaruh Profitabilitas, Operating Leverage, Likuiditas Terhadap Nilai Perusahaan Dengan Struktur Modal Sebagai Intervening. Accounting Analysis Journal, Volume 3(nomor 1), 155-463.

Yasa, K. D. M., \& Wirawati, N. G. P. (2016). Pengaruh Net Profit Margin, Current Ratio, Dan Debt To Equity Ratio Pada Dividend Payout Ratio. E-Jurnal Akuntansi Universitas Udayana Vol. 16(No. 2), 921-950. 